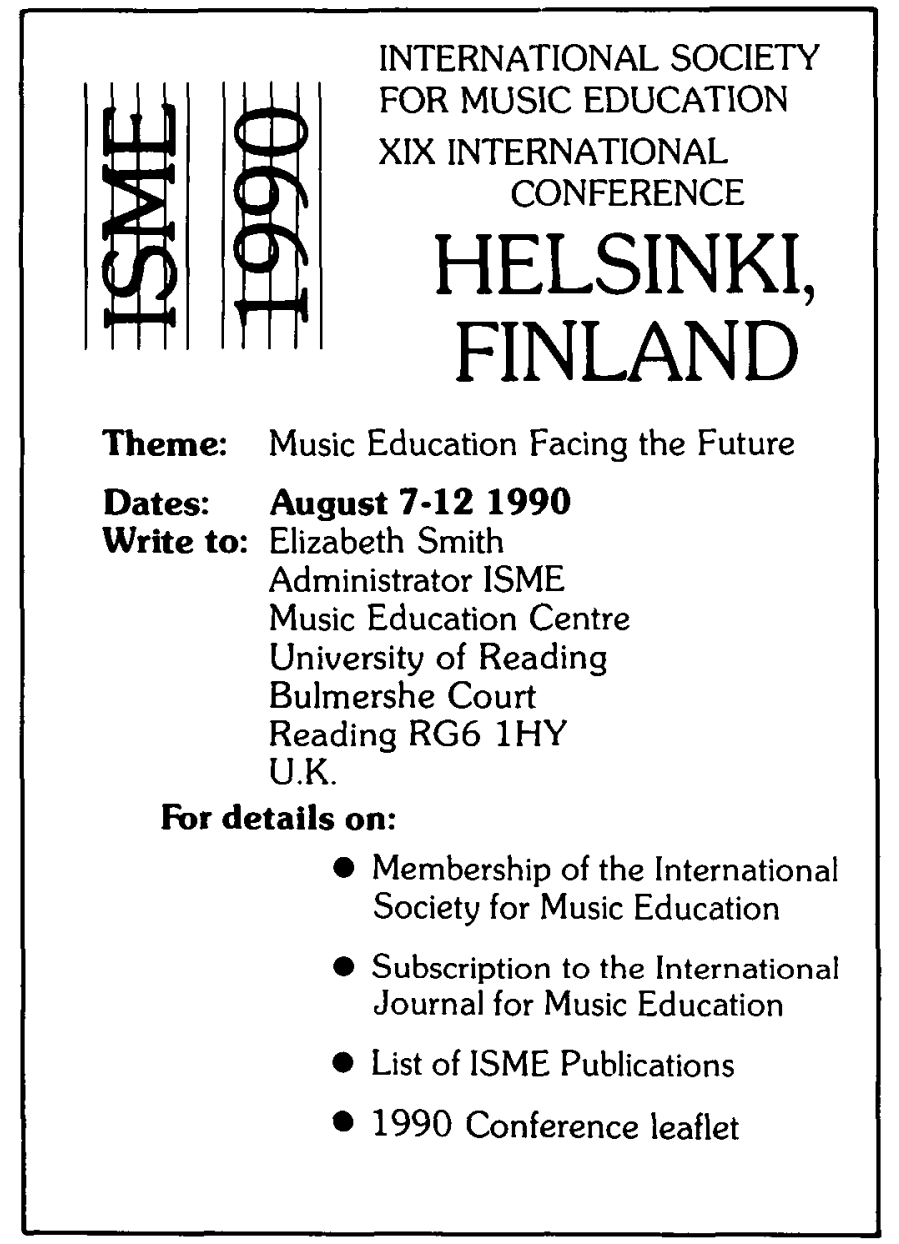




\section{Popular Music}

Co-ordinating editors: David Horn, Director, Institute of Popular Music, University of Liverpool; Richard Middleton, Senior Lecturer in Music, The Open University

The multi-disciplinary 'popular music' journal

Why subscribe to Popular Music?

Popular Music is a vibrant multi-disciplinary journal which covers all aspects of popular music broadly defined; from Abba to zydeco, from broadside ballads to hip-hop. The results of scholarly work are presented in an accessible form, while at the same time responding to current events.

\section{Contents}

In an exciting format, Popular Music contains:

- substantial, authoritative and well regarded articles

- shorter topical pieces - news - correspondence and responses to previous articles $\bullet$ reviews $\bullet$ booklists annotated bibliographies of recent publications in the field

\section{Essential reading for}

- teachers and students - musicologists $\bullet$ anthropologists

- social historians • sociologists

Subscriptions 1990, Volume 9, January, May and October: $£ 22$ for individual subscribers; $£ 40$ for institutions; airmail £9.50 per year extra ISSN 0261-1430

To subscribe, or for further information, please contact: Journals Publicity Department, Cambridge University Press, *FREEPOST, The Edinburgh Building, Shaftesbury Road, Cambridge CB2 1BR, England

("No postage required if posted in the UK)

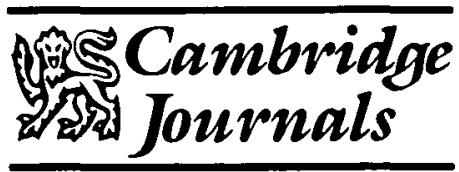




\section{Interested in Drama?}

\section{Two important drama journals from Cambridge!}

\section{New Theatre Quarterly}

New Theatre Quarterly is the literary forum where theatrical scholarship and practice meet. Its hard hitting articles question prevailing assumptions in the theatre world. NTQ follows four independent premises:

- theatre needs a philosophy

- theatre studies need a methodology

- criticism needs a language

- theatre history has contemporary relevance

Features of NTQ include interviews, debates, and book reviews. Articles cover Geography, Politics, History, Education - all aspects of life as they relate to the theatrical world.

Subscriptions 1990, Volume 6: February, May, August and November: $£ 17$ for individuals; $£ 30$ for UK institutions; $£ 32$ for institutions elsewhere; airmail $£ 10$ per year extra ISSN 0266-464X

\author{
"Every college library - \\ every drama department - \\ every student of theatre - \\ every theatre-goer has to \\ subscribe' \\ Eric Bentley
}

"... the best theatre magazine I know of in English..." Edward Bond

"I collect NTQ. I use it. I keep having to refer to it."

Arnold Wesker

"We should thank our lucky stars that NTQ has been around to stimulate the clapped-out brain cells of the English theatre"

Charles Marowitz

\section{Themes in Drama}

A beautifully published annual hardback journal - each volume brings together reviews and articles on the dramatic and theoretical activity of a wide range of cultures and periods. Contributions are written by specialists but are interesting and captivating for everyone. Each volume concentrates on a theme of cultural and continuing importance. Volume 12, 1990, considers ways in which philosophy and theatre have been related.

Subscriptions 1990, Volume 12: March: $£ 20$ for individuals; $£ 35$ for institutions; airmail $£ 6$ per year extra ISSN 0263-676X

To subscribe, or for further information, please contact: Journals Publicity Department, Cambridge University Press, "FREEPOST, The Edinburgh Building, Shaftesbury Road, Cambridge CB2 1BR, England ( No postage required if posted in the UK) 


\section{NOTES FOR CONTRIBUTORS}

The prime aims of the Journal are that articles should be of interest to teachers of music and show evidence of careful and critical enquiry.

Contributions and correspondence should be sent to one of the Editors:

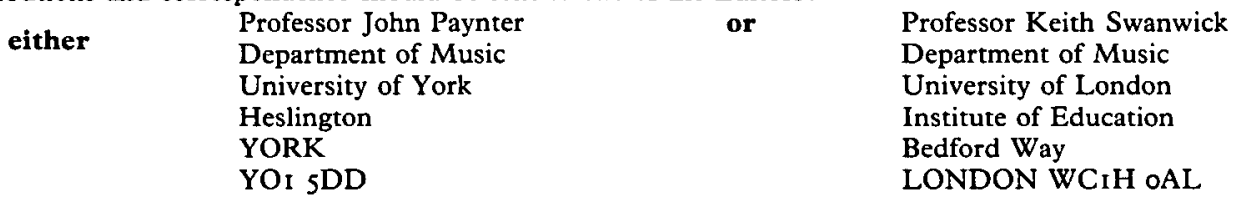

Material for review and review copy should be sent to the Review Editor:

Andrew Peggie, 4 Colchester Avenue, Manor Park, London, E12 5LE

\section{SUBMITTED ARTICLES AND REVIEWS}
Language
Stereotyping
Length
Format
Abstract
Copies

It is hoped that writers will take the opportunity to present musical examples on tape. Usually a cassette tape is produced once a year, normally following the third issue of the Journal. It will have a maximum duration of forty minutes and may refer to articles in each of the issues.

\section{SUBMITTED}

TAPES

ACCEPTED

ARTICLES

AND REVIEWS
Type

Quality

Content

Examples

Proofs

Copyright

Offprints cassette or open-reel.

the highest possible to facilitate transfer.

in final edited form.

should not be numbered on the tape; a written numbered list of items should be provided.

writers have the opportunity, with a given deadline, of correcting essential factual errors and any printer's errors.

writers are responsible for obtaining necessary permissions to quote copyright material; writers will be requested to assign their copyright to Cambridge University Press.

25 free offprints are supplied to writers of published articles, these shared between joint authors; further offprints may be purchased if ordered at proof stage. 


\section{QUOTATIONS AND REFERENCES}

Please identify these in the text by author and by date in brackets, e.g. '(Holmes, 198I)', and list all references alphabetically by surname on a separate sheet at the end:

\begin{tabular}{|c|c|c|c|c|}
\hline format & for books state & for articles state & $\begin{array}{c}\text { for articles in } \\
\text { books state }\end{array}$ & $\begin{array}{l}\text { other notes only } \\
\text { if essential }\end{array}$ \\
\hline $\begin{array}{l}\text { type in double- } \\
\text { spacing on } \mathrm{A}_{4} \\
\text { or equivalent }\end{array}$ & $\begin{array}{l}\text { surname, initials } \\
\text { publication date } \\
\text { (in brackets) } \\
\text { title (underlined) } \\
\text { place of } \\
\text { publication } \\
\text { publisher }\end{array}$ & $\begin{array}{l}\text { surname, initials } \\
\text { publication date } \\
\text { (in brackets) } \\
\text { full title (not } \\
\text { underlined) } \\
\text { journal title } \\
\text { (underlined) } \\
\text { volume number } \\
\text { issue number } \\
\text { page number(s) }\end{array}$ & $\begin{array}{l}\text { author's name } \\
\text { publication date } \\
\text { (in brackets) } \\
\text { title (in quotes) } \\
\text { 'in' } \\
\text { editor's name } \\
\text { book title } \\
\text { (underlined) } \\
\text { place of } \\
\text { publication } \\
\text { publisher }\end{array}$ & $\begin{array}{l}\text { number } \\
\text { consecutively } \\
\text { number in } \\
\text { superscript } \\
\text { list on separate } \\
\text { sheet at end }\end{array}$ \\
\hline
\end{tabular}

$\begin{array}{lll}\text { Please note: 'Eds' } & \text { without point } \\ \text { ' } \& \text { ' } & \text { for joint authors and in publishers' names }\end{array}$

FOR EXAMPLE Alvin, J. (1975) Music Therapy. London: John Clare.

Boyd Willard L. (1984) 'Music: basic education'. In Donald A. Shetler (Ed), The Future of Musical Education in America, vol. 3, pp. 321-7. Rochester, NY: Eastman School of Music Press.

Holmes, M. (198I) The secondary school in contemporary western society: constraints, imperatives, and prospects. Curriculum Inquiry, 15, I, 7-36.

Howe, I. (1985) 'A plea for pluralism'. In Beatrice \& Ronald Gross (Eds), The Great School Debate, pp. 36I-2. New York: Simon \& Schuster.

Scherer, K. R. \& Ekman, P. (Eds) (1984) Approaches to Emotion. Hillsdale, NJ : Erlbaum \& Associates.

\section{ILLUSTRATIONS}

\section{captions}

list and number consecutively on a separate sheet

\section{photographs}

use well-contrasted black and white prints, preferably portrait style no smaller than text width ( $143 \mathrm{~mm}$ ) with glossy finish; lightly put writer's name and figure number on the back in pencil

\section{drawings and diagrams}

use Indian ink and strong paper, white card, or good quality tracing paper 


\section{BRITISH JOURNAL OF MUSIC EDUCATION}

\section{Volume 7 Number 2, July 1990}

\section{CONTENTS}

The Contributors

Gordon Cox: The Legacy of Folk Song: The Influence of Cecil Sharp on Music Education

Gordon Dalgarno: Improving on What is Possible with Hearing Aids for Listening to Music

Jane Southcott: A Music Education Pioneer-Dr Satis Naronna Barton Coleman

Richard Addison: Parents' Views on their Children's Musical Education in the Primary School: A Survey

Gloria Toplis: Playing by Ear: A Classroom Activity

Adele Drake and Judith Robinson: Music. Microtechnology and Handicapped People

\section{BOOK REVIEWS}

(C) Cambridge University Press 1990

Cambridge University Press

The Pitt Building, Trumpington Street, Cambridge CB2 IRP

40 West 20th Street, New York, NY IOOI I, USA

Io Stamford Road, Oakleigh, Melbourne 3166, Australia

Printed in Great Britain by the University Press, Cambridge 